\title{
Effect of UV-C radiation on basic indices of growth process of winter wheat (Triticum aestivum L.) seeds in pre-sowing treatment
}

\author{
Anatoly SEMENOV ${ }^{1}$, Irina KOROTKOVA ${ }^{2,3}$, Tamara SAKHNO ${ }^{1,2}$, Mykola MARENYCH ${ }^{4}$, Volodymyr \\ HANHUR $^{5}$, Viktor LIASHENKO ${ }^{5}$, Viktor KAMINSKY ${ }^{6}$
}

Received March 19, 2020; accepted July 03, 2020.

Delo je prispelo 19. marca 2020, sprejeto 03. julija 2020

Effect of UV-C radiation on basic indices of growth process of winter wheat (Triticum aestivum L.) seeds in pre-sowing treatment

Abstract: An investigation of the effects of UV-C radiation from source having the power of $20 \mathrm{~W}$ on improvement of seed quality of Ukrainian winter wheat (Triticum aestivum L.) six cultivars: 'Gratsiia Myronivska,' 'Trudivnytsia Myronivska', 'Vezha Myronivska', 'Mudrist Odeska', 'Nyva Odeska' and 'Lira Odeska', has been done. In the performed experiment the UV-C irradiation in the range of $50-1000 \mathrm{~J} \mathrm{~m}^{-2}$ was applied. Based on the experimental results it is concluded that irradiation of UV-C on wheat seeds stimulated the seed vigour and germination. It has been established the optimal irradiation dose of UV-C radiation - $250 \mathrm{~J} \mathrm{~m}^{-2}$ for 'Trudivnitsia Myronivska', 'Mudrist Odeska', 'Nyva Odeska', 'Lira Odeska' cultivars and $500 \mathrm{~J} \mathrm{~m}^{-2}$ for 'Hratsiia Myronivska' and 'Vezha Myronivska' cultivars, which leads to maximum effect. The highest biometric indices of seedling structural elements were obtained from the seeds of all wheat cultivars, for which the values of seed vigour and germination were also maximum ones, i.e. at the same irradiation dose.

Key words: seed vigour; germination; UV-C radiation; biometric indices; exposure dose
Učinki predsetvenega UV-C obsevanja semen ozimne pšenice (Triticum aestivum L.) na osnovne indekse rasti

Izvleček: V raziskavi so bili preučevani učinki UV-C obsevanja, moči $20 \mathrm{~W}$, na izboljšanje kakovosti semen sedmih sort ukrajinske ozimne pšenice Triticum aestivum 'Gratsiia Myronivska', 'Trudivnytsia Myronivska', 'Vezha Myronivska', 'Mudrist Odeska', 'Nyva Odeska' and 'Lira Odeska'. $\mathrm{V}$ poskusu je bilo uporabljeno UV-C sevanje jakosti od 50 do $1000 \mathrm{~J} \mathrm{~m}^{-2}$. Rezultati so pokazali, da je UV-C sevanje pospešilo vigor pšeničnih semen in njihovo kalitev. Optimalne doze UV-C sevanja so bile za 'Trudivnitsia Myronivska', 'Mudrist Odeska', 'Nyva Odeska', 'Lira Odeska' $250 \mathrm{~J} \mathrm{~m}^{-2}$ in $500 \mathrm{~J} \mathrm{~m}^{-2}$ za 'Hratsiia Myronivska' in 'Vezha Myronivska'. Največje vrednosti biometričnih indeksov strukturnih elementov sejank so bile za vse sorte pšenice dosežene pri isti dozi obsevanja kot maksimalne vrednosti vigorja semen in kalitve

Ključne besede: vigor semen; kalitev; UV-C sevanje; biometrični indeksi; izpostavitvena doza

\footnotetext{
1 Poltava University of Economics and Trade, Faculty of Commodity science, Trade and Marketing, Department of Commodity research, Biotechnology, Expertise and Customs, Poltava, Ukraine

2 Poltava State Agrarian Academy, Faculty of Agro-Technology and Ecology, Department of Biotechnology and Chemistry, Poltava, Ukraine

3 Corresponding author, e-mail: 2irinakorotkova10@gmail.com

4 Poltava State Agrarian Academy, Faculty of Agro-Technology and Ecology, Department of Selection, Seed Growing and Genetics, Poltava, Ukraine

5 Poltava State Agrarian Academy, Faculty of Agro-Technology and Ecology, Department of Plant, Poltava, Ukraine

6 NSC "Institute of Agriculture" NAAS of Ukraine, Kyiv region, Ukraine
} 


\section{INTRODUCTION}

In the context of seed technology, using physical methods to increase crop productivity has significant advantages in comparison with traditional methods of seed treatment based on chemical compounds (Araújo et al., 2016). Anthropogenic changes of soil, water, and atmosphere as a result of using various chemical additives to increase plant capacity causes searching of the alternative safe methods to increase yields. Such methods envisage the reducing of application of chemical substances or their replacement by physical methods. Among the physical methods used for pre-sowing seed treatment, the following ones are studied most of all: magnetic field, gamma rays, and UV radiation (Govindaraj et al., 2017; Surjadinata et al., 2017). The effectiveness of pre-sowing seeds treatment with electroozonation was proved (Normov et al., 2019).

The results of numerous studies confirm the possibility of magnetic field application for pre-sowing treatment and improving the quality of cereal seeds and in the bean (Balakhnina et al., 2015; Mroczek-Zdyrska et al., 2016; Lazim \& Nasur, 2017). There are many hypotheses explaining the action of magnetic fields on seeds and plants, but they are selective. Therefore, the studies to determine the possibility of applying an alternating magnetic field as a factor affecting seed material quality improvement are being continued at present (Pietruszewski \& Kania, 2010; Rochalska et al., 2011).

The biological effect of gamma radiation on the main components of wheat cells was studied in Ahmed et al. (2017) and Nazarenko \& Izhboldin (2017). It has been established that treatment with gamma radiation leads to changes in the cell structure and cell membrane, photosynthesis, causes the modulation of anti-oxidative system and contributes to the accumulation of phenolic compounds. This effect depends on the radiation dose.

During the previous two decades, a considerable number of experimental papers have been devoted to the study of biological effects and mechanisms of UV radiation influence on plants (Semenov et al., 2017; Kondrateva et al., 2019; Pournavab et al., 2019). There are three potential targets for UV radiation in plant cells: genetic system, photosynthetic system, and membrane lipids. These changes ultimately lead to decreased biomass production and grain yield. The studies of ultraviolet radiation, its doses and other environmental conditions' effect on photosynthesis are of greatest interest (Wenke \& Qichang, 2012; Sugimoto, 2013).

It should be noted that the effect of UV radiation on the biology of seeds and their germination is not well understood (Rupiasih \& Vidyasagar, 2016). It is known, that seeds react to UV radiation, both as on wave length pre- sent in the sunlight (UV-A and UV-B), and wave length below $280 \mathrm{~nm}$ (UV-C). But, at present, there is still not enough information about the possible application of $\mathrm{UV}-\mathrm{C}$ radiation as a stimulating seed treatment.

The stimulating effect of UV-A radiation on legume (Vigna radiata L.) seeds is described in (Hamid \& Jawaid, 2011). It is mentioned here that pre-treatment of seed with UV-A $(366 \mathrm{~nm})$ radiation improves the germination rate, specific leaf area, dry mass, length of roots and shoots as compare to UV-C (254 nm) exposed seed. It is one of the few studies on positive effect of UV-A radiation.

Ultraviolet-B (UV-B) radiation has long been perceived as a stressor. Oxidative stress is flagged as a key factor in such UV-B exposure. Measurements of antioxidants and antioxidant genes show that both low and high doses of UV-B radiation change reactive oxygen species (ROS) metabolism. The elevated level of UV-B radiation can cause a deterioration of seed quality, in particular, contribute to a decrease in protein content, and the total amount of free amino acids (Choudhary \& Agrawal, 2014). The authors connect the reduction of protein content with ROS generation, which causes protein oxidative damage. Another reason of seed quality degradation can be the modification and destruction of amino acids under the influence of UV radiation (Peykarestan \& Seify, 2012). The obtained results of growth parameters were inversely related to the irradiation doses.

Despite the damaging potential of UV-B photons, which limits photosynthesis and plant growth (Hideg et al., 2013; Choudhary \& Agrawal, 2014) it becomes more evident that UV damage is probably the exception than the rule. Thus, the damaging effect of UV-B radiation has now been considered rare. The positive effects of UV-B radiation cover such important areas as stimulation of secondary metabolism, natural means of plant protection, phyto-reagent production and many others (Ballaré et al., 2011). However, as a rule, UV-B radiation is effective only when it lasts for a sufficiently long period of time, usually for several hours or days.

Numerous studies indicate the positive influence of UV-C on seed health, germination and seedling strength of various crops, and also on physiological and biochemical processes in seeds and plants depends on radiation dose (Ouhibi, 2014; Badridze et al., 2016; Castronuovo et al., 2017; Semenov et al., 2018a; Semenov et al., 2018b; Gandhi et al., 2019; Sadeghianfar et al., 2019). But, despite extensive experimental material, fundamental and applied researches are still necessary to determine the optimal irradiation dose, exposure time, depending on plant cultivars and the environment (temperature, humidity).

The aim of this study is to examine the effects of the 
pre-sowing seed treatment of winter wheat (Triticum aestivum L.) with different doses of UV-C radiation (from 50 to $1000 \mathrm{~J} \mathrm{~m}^{-2}$ ) on the basic parameters of seed quality: seed vigour and germination as well as growth parameters like length of seedlings shoots and roots.

\section{MATERIALS AND METHODS}

Three winter wheat (Triticum aestivum L.) cultivars from 2018 harvest, 'Gratsiia Myronivska' (1), 'Trudivnitsia Myronivska' (2) and 'Vezha Myronivska' (3), were supplied by the V. M. Remeslo Myronivka Institute of wheat National Academy of Agrarian Sciences of Ukraine. Three winter wheat cultivars from 2018 harvest, 'Mudrist Odeska' (4), 'Nyva Odeska' (5) and 'Lira Odeska' (6), were supplied by the Plant Breeding and Genetics Institute - National Center of Seed and Cultivar Investigation, National Academy of Agrarian Sciences of Ukraine. Experimental studies were carried out in Grain Quality Laboratory of Poltava State Agrarian Academy during 2019.

The seed material was split into two groups: the control and experimental (UV-C). Control seeds were not irradiated. The sample of each cultivar consisted of 100 seeds. The UV lamp of ZW20D15W type (Semenov et al., 2015), $20 \mathrm{~W}$ power was used as irradiation source. The intensity of energy irradiation at a distance of $1 \mathrm{~m}$ reached 62-69 $\mathrm{W} \mathrm{cm} \mathrm{cm}^{-2}$. The measurements of UV-C radiation dose were conducted with the radiometer "Tensor-31" in the range of 200-280 $\mathrm{nm}$ (Tensor LLC, Ukraine) using the technique (Semenov et al., 2019).

The seeds of each winter wheat cultivar (100 seeds in quadruple repetitions), including control samples, were placed in a plastic tray on filter paper moistened with distilled water and kept at a temperature of $7 \pm 2{ }^{\circ} \mathrm{C}$ for 1 day. Seeds were placed in tray at a distance of $0.5 \mathrm{~cm}$ from each other. Then the cooled samples (except the control ones) were irradiated with UV-C doses of 50-1000 J m ${ }^{-2}$ with the step of $50 \mathrm{~J} \mathrm{~m}^{-2}$. The seeds in a single layer were $\mathrm{UV}-\mathrm{C}$ irradiated on a grid with a cell diameter of $2 \mathrm{~mm}$. The distance between lamps and samples was $25 \mathrm{~cm}$. Irradiation was carried out simultaneously from above and below. By varying of exposure time and distance to the UV source the necessary radiation dose was created.

The seed samples irradiated with different UV-C radiation doses and the control samples were germinated at air temperature of $24 \pm 2{ }^{\circ} \mathrm{C}$ with the light period of $12 / 12 \mathrm{~h}$ for 14 days.

The seed vigour was determined on day 4 , and the germination (the number of seeds that gave normal seedlings in $\%$ of 100 seeds) was determined on day 8 . As the normal seedlings were considered seedlings with root equal to or more than the length of a seed, and with shoot equal to half of seed length (ISTA, 2017). Further on, the indices of seeds irradiated with different UV-C radiation doses were compared with the non-irradiated control samples. After 14 days of the experiment biometric measurement were conducted. The basic growth parameters such as the average root and seedling lengths were measured with $0.1 \mathrm{~cm}$ precision. Biometric measurements were performed in quadruple repetitions for selected 30 seeds at the same physiological age.

The data obtained from the germination and seed vigor laboratory tests were analyzed with the Statistica 10.0 software, where a completely randomized scheme was applied with a bi-factorial arrangement: Factor 1 consisted of the six wheat seeds cultivars, and Factor 2 consisted of the five radiation doses with triplicate repetitions. The statistical data processing was carried out to determine whether there was a significant difference between the means of the treatments. Experimental data was also statistically analyzed for the analysis of variation (ANOVA) and least significant difference (LSD).

\section{RESULTS AND DISCUSSION}

The reaction of six winter wheat cultivars to different doses of UV-C radiation, showed the stimulating effect of this method of seed treatment. The obtained results of seed vigour and germination are presented graphically in Figures 1 and 2.

As can be seen from Figure 1, seed vigour of 'Gratsiia Myronivska' and 'Vezha Myronivska' cultivars, as a result of $500 \mathrm{~J} \mathrm{~m}^{-2}$ exposure dose, increased by $37 \%$ and $31 \%$, respectively, compared to the control samples. The UV-C irradiation wheat seeds by a higher dose of $1000 \mathrm{~J} \mathrm{~m}^{-2} \mathrm{re}-$ sulted in decrease of seed vigour to $21-25 \%$ as compared with the seed vigour at irradiation dose of $500 \mathrm{~J} \mathrm{~m}^{-2}$ and to $17-18 \%$ at irradiation dose of $250 \mathrm{~J} \mathrm{~m}^{-2}$. It should be noted that at seed treatment of 'Gratsiia Myronivska' and 'Vezha Myronivska' cultivars with a dose of $1000 \mathrm{~J} \mathrm{~m}^{-2}$ the number of germinated samples remains at the control level (70 \%) taking into account measurement accuracy. This fact indicates a decrease in effectiveness of high radiation doses impact on the seed vigor of these cultivars in comparison with lower radiation doses.

The highest value of seed vigour in 'Trudivnitsia Myronivska', 'Mudrist Odeska', 'Nyva Odeska, 'Lira Odeska' cultivars was registered at a dose $250 \mathrm{~J} \mathrm{~m}^{-2}$. Comparing seed vigour after treatment relative to the control one can notice an improvement of about $8 \%$ for 'Trudivnitsia Myronivska' cultivar, and of about 30-37 \% for 'Mudrist Odeska, 'Nyva Odeska' and 'Lira Odeska' cultivars. Increasing of the irradiation dose to $500 \mathrm{~J} \mathrm{~m}^{-2}$ resulted in 


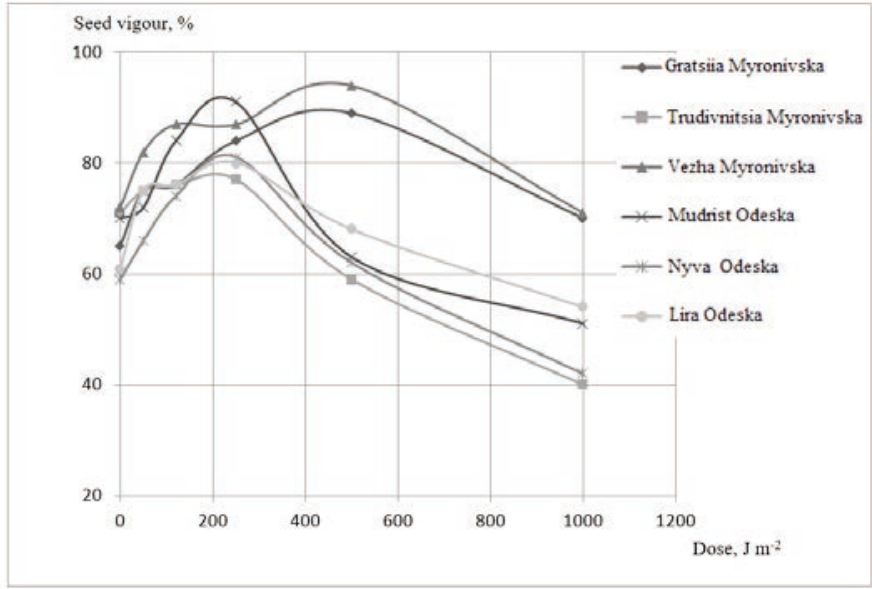

Figure 1: The effect of different dose of UV-C treatment on seed vigour of winter wheat seeds

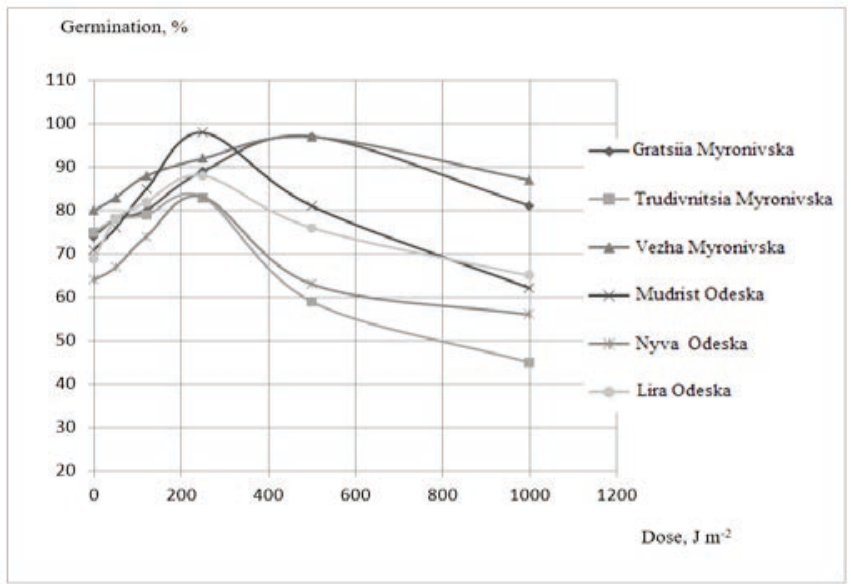

Figure 2: Effect of pre-sowing wheat seed treatment with different dose of UV-C radiation on germination

decrease of seed vigour to $15-31 \%$ as compared with the control. As a result of exposure to a higher dose of $1000 \mathrm{~J} \mathrm{~m}^{-2}$, the seed vigour of 'Trudivnitsia Myronivska', 'Mudrist Odeska' and 'Nyva Odeska' cultivars decreased compared with control by 27-44\% and of 'Lira Odeska' cultivar by $12 \%$.

Thus, the obtained results confirm that applying UV-C irradiation with doses of 500-1000 J m-2 for presowing seed treatment of 'Gratsiia Myronivska' and 'Vezha Myronivska' cultivars, and a dose of $1000 \mathrm{~J} \mathrm{~m}^{-2}$ for 'Trudivnitsia Myronivska, 'Mudrist Odeska, 'Nyva Odeska' and 'Lira Odeska' cultivars will definitely have worsened effect on the sowing qualities of the studied wheat cultivars' seeds.

The magnitude of seed vigour correlates well with germination, which is of interest for present research. The stimulating effect of UV irradiation was found for all wheat seed cultivars including those with low germination in control: for 'Nyva Odeska' and 'Lira Odeska' cul- tivars the control germination amounted of about $64 \%$ and $69 \%$, respectively (Figure 1, 2).

As a result of UV treatment with a dose $250 \mathrm{~J} \mathrm{~m}^{-2}$, germination of 'Nyva Odeska' cultivar increased by $30 \%$ and amounted to $83.3 \%$, and germination of 'Lira Odeska' cultivar increased by $27 \%$ and amounted to $88 \%$. It should be noted that the germination of 'Nyva Odeska' cultivar after treatment of $500 \mathrm{~J} \mathrm{~m}^{-2}$ practically did not change as compared with the control and amounted $63 \%$. The maximum germination of $98 \%$ among all tested cultivars was registered for seeds of 'Mudrist Odeska' cultivar for irradiation dose of $250 \mathrm{~J} \mathrm{~m}^{-2}$. The irradiation of seeds this cultivar by a dose $250 \mathrm{~J} \mathrm{~m}^{-2}$ led to an increase in germination on $38 \%$ as compared to control seeds.

Weak effect of UV radiation was observed for seeds of 'Trudivnitsia Myronivska' cultivar at irradiation doses of a smaller range from 50 to $200 \mathrm{~J} \mathrm{~m}^{-2}$. Only as a result of seed treating by dose of $250 \mathrm{~J} \mathrm{~m}^{-2}$ the germination increase by $10.7 \%$ was observed. 
The seeds of 'Gratsiia Myronivska' and 'Vezha Myronivska' cultivars turned out to be the most sensitive to UV-C of $500 \mathrm{~J} \mathrm{~m}^{-2}$ exposure doses as in determining seed vigour. Germination of these cultivars after treatment increased by $31.1 \%$ and $21.1 \%$, respectively, compared with the control.

With increasing radiation dose to $1000 \mathrm{~J} \mathrm{~m}^{-2}$ there was a decrease of germination by 6-13\% for 'Mudrist Odeska', 'Nyva Odeska' and 'Lira Odeska' cultivars (Figure 2). At such radiation dose, the lowest germination of 'Trudivnitsia Myronivska' cultivar seeds (about $45 \%$ ) was registered, which on $40 \%$ lower the germination of the control sample (75\%). This is the lowest index of germination for all the tested cultivars obtained as a result UV-C radiation treatment.

It can be determined from the established dependence of seed vigor and germination on UV-C radiation dose (Figure 1,2) that the optimal dose for pre-sowing seed treatment of the 'Trudivnitsia Myronivska', 'Mudrist Odeska', 'Nyva Odeska', 'Lira Odeska' cultivars is $250 \mathrm{~J}$ $\mathrm{m}^{-2}$ and $500 \mathrm{~J} \mathrm{~m}^{-2}$ for 'Hratsiia Myronivska' and 'Vezha Myronivska' cultivars. As a result of seed treated with optimal doses the seed vigor and germination are the highest. Our results confirm the data from the study by Tertyshnaya et al. (2018) on examining the impact of UV-B radiation $(365 \mathrm{~nm})$ on seed germination of spring and winter wheat. The authors have shown that wheat germination 'Moskovskaya 39' (67\%), 'Yubileynaya 100 ' (92\%), 'Dar'ya' (98\%) and 'Afina' (99\%) cultivars increased by $1-3 \%$ as a result of seed treatment. Insignificant germination increases as compared to our results can be explained by the difference in wavelength of UV-B and UV-C ranges, and as a consequence, different irradiation efficiencies.

A significant increase in germination by $38 \%$ at the established optimal radiation dose of $250 \mathrm{~J} \mathrm{~m}^{-2}$ obtained in present study (the investigated range is 50-1000 $\mathrm{J} \mathrm{m}^{-2}$ ) is in consistent with results observed in Rupiasih \& Vidyasagar (2016), where the influence of different period of exposure (30, 60, 90, 120 and 180 minutes) using a UV-C source from Pride $(240 \mathrm{~V}, 50 \mathrm{~Hz} ; 20 \mathrm{~W})$ on the effectiveness of wheat seeds germination has been studied. The results showed that there is no direct dependence between the exposure periods and seed germination. Maximum germination of $96.7 \%$ was recorded at $180 \mathrm{~min}$ UV-C irradiation treatment, and it was low (83.3\%) at 60 min UV-C treatment that is equal to control. At the same time, the minimum germination of $67 \%$ was recorded at 120 min treatment (Rupiasih \& Vidyasagar, 2016).

The similar dependence was also observed for seeds of other crops, as shown in study by Siddiqui et al. (2011). An experiment was conducted on seeds of mung bean (Vigna radiata (L.) Wilczek and groundnut (Arachis hypogaea L.) exposed to ultraviolet (UV-C $<280 \mathrm{~nm}$ ) radiations for $0,5,10,15,20,30$ and 60 minutes' period. As a result, the optimal exposure time leading to the seed stimulation of these crops was determined. UV-C exposure seed for $30 \mathrm{~min}$ period gave significant result in increment of germination of mung bean (up to $100 \%$ ) and groundnut (up to $86.66 \%$ ).

According to the results of multi-factor analysis of variance (Factorial ANOVA) it has been revealed that cultivars properties play an important role in genotype reaction on irradiation factor in determining seed vigor $\left(\mathrm{LSD}_{05}=2.0 \%\right)$. The value of least significant difference $\left(\mathrm{LSD}_{05}\right)$ was $4.5 \%$ for factor interaction and $5.0 \%$ for the index of seed laboratory germination.

Thus, it was found that $28 \%$ of the total seed vigor variation is explained by cultivar properties, and $67 \%$ due to the radiation dose. For germination indices, these values were almost the same, namely $46 \%$ of the total germination variation was stipulated by cultivar characteristics, and $47 \%$ - by radiation dose.

The analysis of variance (Table 1) showed that wheat cultivar characteristics play a much smaller role for seed vigor as compared with germination.

The value of $\mathrm{F}$ criterion in calculating seed vigor for the cultivar factor and for the radiation dose factor was 117.38 and 285.36 respectively. The value of germination depended on cultivar characteristics and irradiation dose

Table 1: Result of the variance analysis to determine the seed vigour and germination

\begin{tabular}{|c|c|c|c|c|c|}
\hline \multirow[b]{2}{*}{ Effect } & \multicolumn{5}{|c|}{ Univariate tests of significance for seed vigour/germination, \% } \\
\hline & SS & Degree of freedom & MS & $\mathrm{F}$ & $p$ \\
\hline Intercept & $551265,3 / 646197,4$ & 1 & $551265,3 / 646197,4$ & $76920,74 / 76023,22$ & 0,00 \\
\hline Cultivar & $4206,0 / 5308,3$ & 5 & $841,2 / 1061,7$ & $117,38 / 124,90$ & 0,00 \\
\hline Dose, $\mathrm{J} \mathrm{m}^{-2}$ & $10225,4 / 5516,1$ & 5 & $2045,1 / 1103,2$ & $285,36 / 129,79$ & 0,00 \\
\hline Cultivar ${ }^{\star}$ Dose, $\mathrm{J} \mathrm{m}^{-2}$ & $4081,2 / 4014,3$ & 25 & $163,2 / 160,6$ & $22,78 / 18,89$ & 0,00 \\
\hline Error & $516,0 / 612,0$ & 72 & $7,2 / 8,5$ & & \\
\hline
\end{tabular}

Note: The table shows the main results of the analysis: Sum-of-Squares (SS), Mean Squares (MS), Degree of freedom, value of F criterion (F), significance levels (p). 


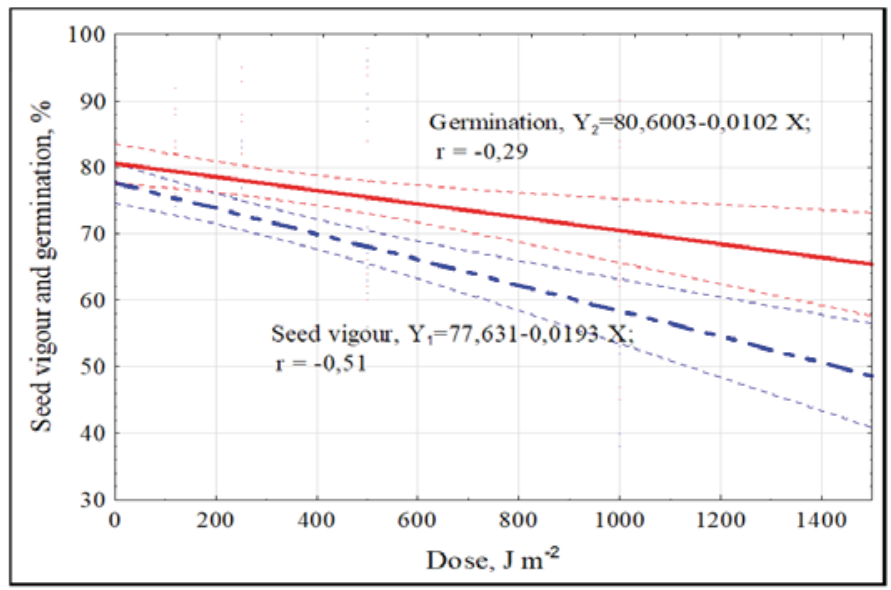

Figure 3: Seed vigour and germination regression plot from UV-C radiation dose

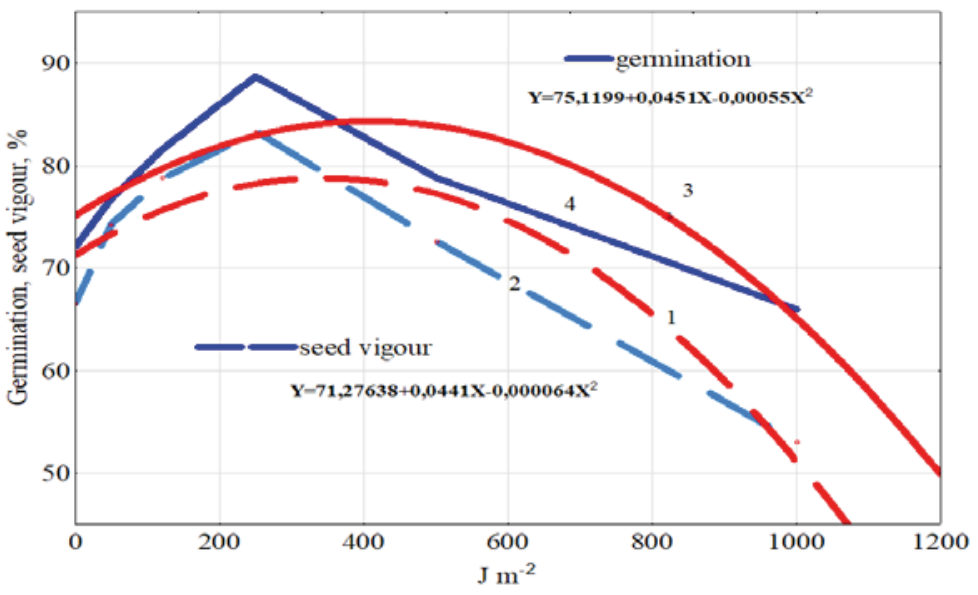

Figure 4: Experimental and theoretical curves dependence of seed vigour $(1,2)$ and germination $(3,4)$ of wheat seeds from dose UV-C treatment (1, 3 - theoretical curves; 2,4 - experimental curves)

almost equally - the interaction of factors at the effect on both indicators was $\mathrm{F}=124.90$ and 129.79 at $p<0.01$.

It was also established that with an increase in radiation dose, the correlation value between the seed vigor and germination increase from $r=0.74$ for the control samples to $\mathrm{r}=0.88$ at radiation dose of $500 \mathrm{~J} \mathrm{~m}^{-2}$. Later this correlation weakened. Thus, it was statistically founded there is an average and weak inverse correlation between the indicators of seed vigour and germination and radiation doses.

The regression equation is presented in Figure 3. The presence of such conformities indicates the probability of the existence of another type of dependence. The analysis of the experimental results by non-linear regression method showed that for the irradiation factor, the graphical dependence has the parabola shape. Experimental curves and theoretical equations of functions' dependence of seed vigor and germination on the radiation dose are given in Figure 4. The theoretical curves were selected in such a way that they reflected the obtained experimental dependence. In our case, the equations of the quadratic function are best superimposed on the experimental curves (parabolas of the form $Y=b_{0}+b_{1} X$ $\left.-\mathrm{b}_{2} \mathrm{X}^{2}\right)$. The regression coefficients in this case are valid at $p<0.01$.

It was experimentally established that the highest values of seed vigor and germination for 'Trudivnitsia Myronivska, 'Mudrist Odeska, 'Nyva Odeska' and 'Lira Odeska' wheat cultivars were obtained at radiation dose of $250 \mathrm{~J} \mathrm{~m}^{-2}$ and for 'Gratsiia Myronivska' and 'Vezha Myronivska' cultivars - at radiation dose of $500 \mathrm{~J} \mathrm{~m}^{-2}$. However, theoretical calculations show that the improvement in seed vigor and germination indices can be achieved under applying 400-500 $\mathrm{J} \mathrm{m}^{-2}$ doses.

Two weeks after sprouting, biometric evaluation of seedling structural elements was conducted. For this 


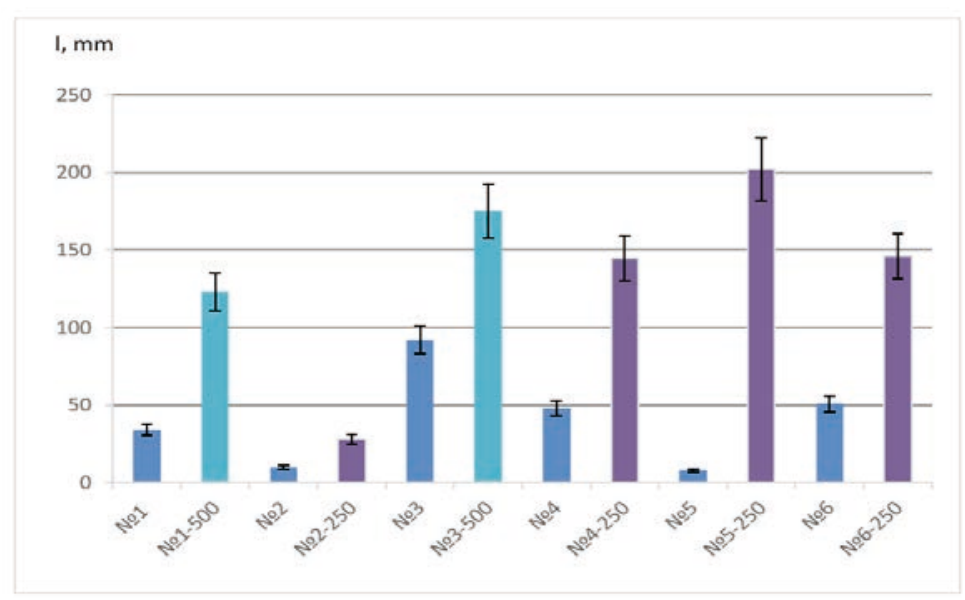

Figure 5: Effect of UV-C radiation on root length of wheat seeds at different exposure dose applied $\left(\mathrm{LSD}_{01}=2.00 \mathrm{~mm}\right)$

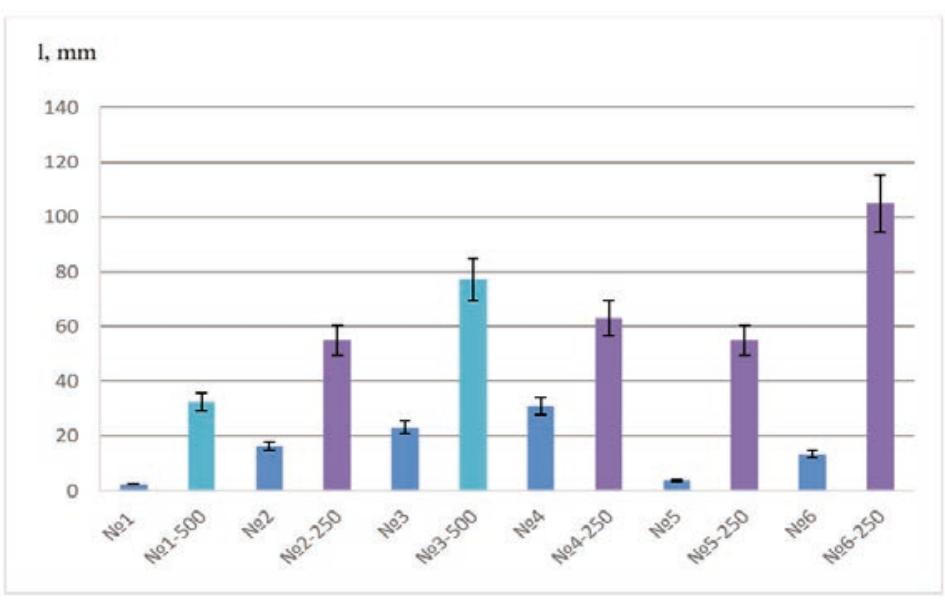

Figure 6: Effect of UV-C radiation on shoot length of wheat seeds at different exposure dose applied $\left(\mathrm{LSD}_{01}=2.2 \mathrm{~mm}\right)$

purpose, 30 seedlings in quadruple repetitions were selected carefully (without breaking the root system) from each of the trays and length of roots and the aboveground parts of plants were measured. The result of UV-C radiation stimulating effect was the improvement of biometric indices in all the investigated cultivar seeds. The height of seedlings and length of root system depending on the dose and cultivar were not the same.

Significant effect of UV irradiation on development of the root system and aboveground part was observed in seeds treated with $250 \mathrm{~J} \mathrm{~m}^{-2}$ and $500 \mathrm{~J} \mathrm{~m}^{-2}$ doses of UV-C radiation, at which seed vigor and germination had maximum values. Length of root system in all wheat cultivars increased by 2.0-3.6 times on the average, and length of shoots increased by 2.0-3.4 times as a result of irradiation (Figure 5, 6).

The maximum effect of UV-C radiation on root length and height of shoots was observed in seeds of 'Nyva Odeska' cultivar. So, the length of seedlings roots exposed with $250 \mathrm{~J} \mathrm{~m}^{-2}$ dose 25 times exceeded length of roots of control samples (Figure 5, №5) and reached $202 \mathrm{~mm}$ (Figure 5, №5-250), and the height of shoots increased by 14.4 times and amounted to $55 \mathrm{~mm}$ (control samples $-3.8 \mathrm{~mm}$ ) as shown at Figure 6. The obtained results correlate well with seed vigour and germination at dose of $250 \mathrm{~J} \mathrm{~m}^{-2}$. The values of seed vigour and germination after treatment compared with the control were founded higher of about $37 \%$ and $30 \%$, respectively. The effect of UV-C irradiation (200-280 nm) on biometric parameters of the wheat cultivars studied by us turned out to be more significant than that described in study Tertyshnaya et al. (2018). As it was established in our experiments, the length of seedlings roots of all the investigated seed cultivars increased by 2-3.6 times, and height of shoots - by 2.0-3.4 times, while the authors of study Tertyshnaya et al. (2018) observed increasing the root length of wheat seedlings treated with UV-B rays (365 $\mathrm{nm}$ ) by only $26-60 \%$. The height of shoots obtained 
from seeds treated with UV-B for 30 minutes increased as compared to control on 30 \% in 'Moskovskaya 39' cultivar, in 'Yubileynaya 100', 'Dar'ya' and 'Afina' cultivars - by only 3-5\%. Insignificant increases of the seedlings root length and shoot height as compared to our results can be explained by the difference irradiation efficiencies of the UV-B and UV-C ranges.

The effectiveness of UV-C ray pre-sowing treatment is shown on the example of mung bean and peanut seeds (Siddiqui et al., 2011), but the optimum exposure time affecting the root length of and seedling height was not determined by the authors. So, maximum shoot height of $22.38 \mathrm{~cm}$ compared with the control $(13 \mathrm{~cm})$ was observed when seeds of mung bean were treated with UV-C for 15 minutes while root length was increased to 19.58 $\mathrm{cm}$ (control $-10.53 \mathrm{~cm}$ ) when seeds were treated for 30 minutes. The increase in shoot length of groundnut seeds $(6.83 \mathrm{~cm}$ vs. $4.91 \mathrm{~cm}$ in the control) was attained when seeds were treated with UV-C radiation for 60 minutes whereas maximum root length was observed in Siddiqui et al. (2011) when seeds were treated with UV-C for 30 minutes ( $18.39 \mathrm{~cm}$ vs. $13.62 \mathrm{~cm}$ in the control).

Dose-dependent reaction of lettuce seeds treated with $0.82 \mathrm{~kJ} \mathrm{~m}^{-2}$ and $3.42 \mathrm{~kJ} \mathrm{~m}^{-2}$ of UV-C radiation dose was established Ouhibi et al. (2014). Seed irradiation with the lowest dose of $0.85 \mathrm{~kJ} \mathrm{~m}^{-2}$ contributed to increasing length of roots and pre-serving dry mass under salinity stress.

However, there are experimental studies indicated the negative effect of UV-C $(254 \mathrm{~nm})$ radiation at different period of exposure for 30 and $60 \mathrm{~min}$ on seeds of various crops compared to untreated seeds (Lazim \& Nasur, 2017). So, at $60 \mathrm{~min}$ exposure time the lowest seedling length $(11.09 \mathrm{~cm})$ which reduced by $(24.04 \%)$ compared to control $(14.6 \mathrm{~cm})$ was observed. Significant effect in root length of sorghum seeds between all treatments periods was not found.

Thus, the obtained results enable to conclude that for different cultivar seeds there is an optimum amount of absorbed radiation energy leading to the maximum effect. These could be attributed to the difference in the structure of the seeds, physiological state, composition, and epidermis thickness of the seeds coat.

\section{CONCLUSIONS}

The present study shows that UV-C radiation may have a significant effect on the sowing properties of the tested winter wheat cultivars of Ukrainian selection. The optimal doses of UV-C radiation - $250 \mathrm{~J} \mathrm{~m}^{-2}$ for 'Trudivnitsia Myronivska, 'Mudrist Odeska', 'Nyva Odeska, 'Lira Odeska' cultivars and $500 \mathrm{~J} \mathrm{~m}^{-2}$ for 'Hratsiia
Myronivska' and 'Vezha Myronivska' cultivars were established. Seed treatment with optimal radiation doses of all wheat cultivars contributed to the increase in seed vigour by $30-37 \%$, and germination by $21-38 \%$ as compared to control samples.

It is shown that UV irradiation positively affects the biometric parameters of wheat seedlings. The root system of irradiated seed samples is more developed than of unexposed ones. As a result of UV-C radiation with established doses, the root length in all the studied wheat cultivars significantly increased by 2.0-3.6 times, and the seedling shoot height - by 2.0-3.4 times. The maximum increase in root length by 25 times and shoot height - by 14.4 times was found in seed seedlings of 'Nyva Odeska'.

The obtained results are of interest and prove the expediency of using UV-C irradiation to increase the sowing qualities of large batches of seeds with reduced germination. The proposed method of stimulating seeds with UV-C radiation can be applied in selection, where sometimes there is a threat of losing small amounts of valuable breeding material with low seed vigour and germination.

\section{REFERENCES}

Araújo, S. de S., Paparella, S., Dondi, D., Bentivoglio, A., Carbonera, D., Balestrazzi, A. (2016). Physical Methods for Seed Invigoration: Advantages and Challenges in Seed Technology. Frontiers in Plant Science, 7, 646. https://doi. org/10.3389/fpls.2016.00646

Ahmed, S., Khan, W.M., Khan, M.S., Akhtar, N., Umar, N., Ali, S., Hussain, S., \& Shah, S.S. (2017). Impact of gamma radiations on wheat (Triticum aestivum L.) varieties (Batoor and Janbaz). Pure and Applied Biology, 6(1), 218-225. https:// doi.org/10.19045/bspab.2017.60017

Balakhnina, T., Bulak, P., Nosalewicz, M., Pietruszewski, S., Włodarczyk, T. (2015). The influence of wheat Triticum aestivum L. seed pre-sowing treatment with magnetic fields on germination, seedling growth, and antioxidant potential under optimal soil watering and flooding. Acta Physiologiae Plantarum, 37, 59. https://doi.org/10.1007/s11738-0151802-2

Ballaré, C.L., Caldwell, M.M., Flint, S.D., Robinson, S.A., Bornman, J. F. (2011). Effects of solar ultraviolet radiation on terrestrial ecosystems. Patterns, mechanisms, and interactions with climate change. Photochemical \& Photobiological Sciences, 10, 226-241. https://doi.org/10.1039/c0pp90035d.

Badridze, G., Kacharava N., Chkhubianishvili E., Rapava L., Kikvidze M., Chanishvili S., Shakarishvili N., Mazanishvili L., Chigladze, L. (2016). Effect of UV radiation and artificial acid rain on productivity of wheat. Russian Journal of Ecology, 47(2), 158-166. https://doi.org/10.1134/ S106741361602003X

Castronuovo, D., Sofo A., Lovelli S., Candido V., Scopa A. (2017). Effects of UV-C radiation on common dandelion 
and purple coneflower: first results. International Journal of Plant Biology, 8(1), 7255. https://doi.org/10.4081/ pb.2017.7255

Choudhary, K. K., \& Agrawal, S.B. (2014). Ultraviolet-B induced changes in morphological, physiological and biochemical parameters of two cultivars of pea (Pisum sativum L.). Ecotoxicology and Environmental Safety, 100, 178-187. https://doi.org/10.1016/j.ecoenv.2013.10.032

ISTA. (2017). International rules for seed testing, 2017 (1): i-556(56). International Seed Testing Association. https://doi. org/10.15258/istarules.2017.05

Gandhi, N., Rahul K., Chandana N., Madhuri B., Mahesh D. (2019). Impact of ultraviolet radiation on seed germination, growth and physiological response of Bengal gram (Cicer arietinum L.) and horse gram (Macrotyloma uniflorum L.). Journal of Biochemistry Research, 2(1), 019-0034.

Govindaraj, M., Masilamani, P., Albert, A.V., \& Bhaskaran M. (2017). Effect of physical seed treatment on yield and quality of crops: A review. Agricultural Reviews, 38(1), 1-14. https://doi.org/10.18805/ag.v0iOF.7304

Hamid, N., Jawaid, F. (2011). Influence of Seed pre-treatment by UV-A and UV-C radiation on germination and growth of Mung beans. Pakistan Journal of Chemistry, 1(4), 164167. https://doi.org/10.15228/2011.v01.i04.p04

Hideg, E., Jansen, M.A.K., \& Strid, A. (2013). UV-B exposure, ROS, and stress: inseparable companions or loosely linked associates? Trends in Plant Science, 18, 107-115. https:// doi.org/10.1016/j.tplants.2012.09.003

Kondrateva, N.P., Krasnolutskaya M.G., Dukhtanova N.V., Obolensky N.V. (2019). Effect of ultraviolet radiation the germination rate of tree seeds. IOP Conf. Series: Earth and Environmental Science, 226: 012049. https://doi. org/10.1088/1755-1315/226/1/012049

Lazim, S.K., \& Nasur A.F. (2017). The effect of magnetic field and ultraviolet-C radiation on germination and growth seedling of sorghum (Sorghum bicolor $L$. Moench). Journal of Agriculture and Veterinary Science, 10(10), 30-36. https://doi.org/ 10.9790/2380-1010023036

Mroczek-Zdyrska, M., Tryniecki L., Kornarzyński K., Pietruszewski S., Gagoś M. (2016). Influence of magnetic field stimulation on the growth and biochemical parameters in Phaseolus vulgaris L. Journal Microbiology, Biotechnology and Food Science, 5(6), 548-551. https://doi.org/10.15414/ jmbfs.2016.5.6.548-551

Nazarenko, M.M., Izhboldin, O.O. (2017). Chromosomal rearrangements caused by gamma-irradiation in winter wheat cells. Biosystems Diversity, 25(1), 25-28. https://doi. org/10.15421/011704

Normov, D., Chesniuk, E., Shevchenko, A., Normova, T., Goldman, R., Pozhidaev, D., Bohinc, T., Trdan S. (2019). Does ozone treatment of maize seeds influence their germination and growth energy? Acta agriculturae Slovenica, 114/2, 251-258. https://doi:10.14720/aas.2019.114.2.10

Ouhibi, C., Attia, H., Rebah, F., Msilini, N., Chebbi, M., Aarrouf, J., Urban, L., Lachaal, M. (2014). Salt stress mitigation by seed priming with UV-C in lettuce plants: Growth, antioxidant activity and phenolic compounds. Plant Physiology and Biochemistry, 83, 126-133. https://doi.org/10.1016/j. plaphy.2014.07.019
Pietruszewski, S., Kania, K. (2010). Effect of magnetic field on germination and yield of wheat. International Agrophysics, 24, 297-302.

Peykarestan, B., Seify, M.R. (2012). UV Irradiation Effects on Seed Germination and Growth, Protein Content, Peroxidase and Protease Activity in Red Bean. International Journal of Science and Engineering Investigations, 1(3), 107-113.

Pournavab, R.F., Mejía E.B., Mendoza A.B., Cruz L.R.S., Heya M.N. (2019). Ultraviolet radiation effect on seed germination and seedling growth of common species from Northeastern Mexico. Agronomy, 9 (6), 269. https://doi. org/10.3390/agronomy9060269

Rochalska, M., Grabowska-Topczewska, K., Mackiewicz, A. (2011). Influence of alternating low frequency magnetic field on improvement of seed quality. International Agrophysics, 25, 265-269.

Rupiasih, N.N., \& Vidyasagar P.B. (2016). Effect of UV-C radiation and hypergravity on germination, growth and content of chlorophyll of wheat seedlings. AIP Conference Proceedings, 1719: 030035. https://doi.org/10.1063/1.4943730

Sadeghianfar, P., Nazari M., \& Backes G. (2019). Exposure to Ultraviolet (UV-C) Radiation Increases Germination Rate of Maize (Zea maize L.) and Sugar Beet (Beta vulgaris) Seeds. Plants, 8(2), 49. https://doi.org/10.3390/plants8020049

Siddiqui, A., Dawar, S., Zaki, M.J., Hamid N. (2011). Role of Ultra Violet (UV-C) radiation in the control of root infecting fungi on groundnut and mung bean. Pakistan Journal of Botany, 43(4), 2221-2224.

Surjadinata, B.B., Jacobo-Velázquez, D.A., Cisneros-Zevallos, L. (2017). UVA, UVB and UVC Light Enhances the Biosynthesis of Phenolic Antioxidants in Fresh-Cut Carrot through a Synergistic Effect with Wounding. Molecules, 22, 668-681. https://doi.org/10.3390/molecules22040668.

Sugimoto, K. (2013). Seed germination under UV-B irradiation. Bulletin Minami-Kyushu University, 43A, 1-9.

Semenov, A., Kozhushko G., Bala L. (2015). No ozone germicidal lamp for plants photochemical and photo biological action. Technological audit and production reserves, 4/1(24), 4-7. https://doi.org/10.15587/2312-8372.2015.46953.

Semenov, A.O., Kozhushko G.M., Sakhno T.V. (2017). Analysis of the role of UV radiation on the development and productivity of different cultures. Light engineering and electricity, 2, 3-16. http://nbuv.gov.ua/UJRN/svitteh_2017_2_3

Semenov, A., Kozhushko, G., Sakhno, T. (2018 a). Influence of pre-sowing UV-radiation on the energy of germination capacity and germination ability of rapeseed. Technology Audit and Production Reserves, 5/1(43), 61-65. https://doi. org/10.15587/2312-8372.2018.1434

Semenov, A.O., Burhu Yu.G., Kozhushko G.M., Marenych M.M., Sakhno T.V. (2018 b). Influence of ultraviolet radiation on germination, sprouting and growth processes of wheat. Bulletin of Poltava State Agrarian Academy, 4, 70-75. https://doi.org/10.31210/visnyk2018.04.10

Semenov, A., Korotkova, I., Sakhno, T., Marenych, N. (2019). The exploiting of agronomic potential of UV-C irradiation for increasing the pre-sowing qualities of the carrot seeds. Ukrainian Black Sea Region Agrarian Science, 1(101), 47-52. https://doi.org/10.31521/2313-092X/2019-1(101)-7

Tertyshnaya, Yu.V., Levina, N.S., Elizarova, O.V. (2018). Impact 
of ultraviolet radiation on germination and growth processes of wheat seeds. Agricultural Machinery and Technologies, 2, 31-36. https://doi.org/10.22314/2073-7599-201811-2-31-36

Wenke, L., \& Qichang, Y. (2012). Effects of day-night supple- mental UV-A on growth, photosynthetic pigments and antioxidant system of pea seedlings in glasshouse. African Journal of Biotechnology, 11(82), 14786-14791. https://doi. org/10.5897/AJB12.2020 